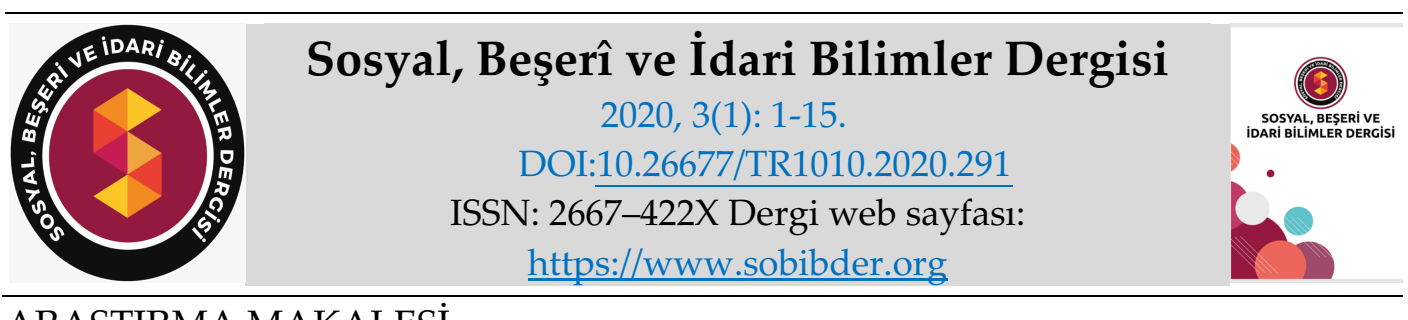

ARASTTIRMA MAKALESI

\title{
15. Yüzyıl Edirne Taş Köprüleri
}

Işıl AKAR, Yüksek Lisans Öğrencisi, Gazi Üniversitesi, Sosyal Bilimler Enstitüsü, Ankara, eposta: isillakar@gmail.com

ORCID: https://orcid.org/0000-0001-5703-8032

\section{Öz}

Osmanlı Mimarlı̆̆ı, 14. yüzyıldan 20.yüzyılının başlarına kadar uzanan; Erken dönem (14.yy15.yy), Klasik Dönem (15.yy-17.yy), Batılılaşma Dönemi (17.yy-19.yy) şeklindeki üç üslûpsal etkinlik sürecinde tarihin en zengin mimarlık repertuvarlarından birisini yaratmıştır. Üç kıtada geniş bir coğrafyada etkili olan Osmanlı mimarlı̆̆ı, zaman içinde büyük değişimler geçirmiş ve kendini, hakim olduğu topraklar üzerinde gelmiş geçmiş tüm kültürlerin sentezini yaparak geliştirmiştir. Bu makalede konu edilecek olan köprü mimarlı̆̆ bu büyük mimarlık geleneğinin en önemli yapı tiplerinden birisidir. İmparatorluğun ilk yıllarından itibaren Avrupa'da bulunan topraklarında çok sayıda köprü yapılmıştır. Osmanlı devleti, bu topraklar üzerindeki küçüklü büyüklü akarsular üzerine yaptığı köprülerle Avrupa'ya açılmıştır. Bu incelemede; Osmanlı'nın bu erken yıllarında yaptığı en önemli köprüler arasında yer alan 15. yüzyıl Edirne köprüleri konu edilmektedir. Osmanlı Döneminde yeni köprülerin inşa edilmesi yanı sıra daha önceki dönemlere ait olanlarda onarılarak kullanılmıştır. Bu durum kültürlerin etkileşimi, eserin mimari özelliklerinin farklı bir bakış açısıyla yeniden yorumlanması gibi durumlara da olanak sağlar. Araştırma konusu olan köprülerin sıklıkla görüldüğü alanlar suyolları bakımından oldukça zengin olan bölgelerdir. Sadece büyük nehirler üzerinde değil daha küçük ve yerleşim içlerinde kalan dereler üzerinde de örnekler görülür. Osmanlı Döneminde önemli bir konumda bulunan Edirne nehirler yönünden zengin oluşuyla köprü mimarisi konusunda oldukça önemli örneklere sahiptir. Bu örneklere sadece şehir merkezinde değil ilçeler ve köylerde de rastlanır. Boyutları, mimari özellikleri, inşa edildikleri dönemler birbirinden farklı olan Edirne köprüleri günümüze çoğunluğu iyi ve sağlam durumda olarak ulaşmıştır. İncelenen köprüler bulundukları nehir, sahip oldukları göz sayısı, kemer biçimleri, süsleme anlayışları, günümüzdeki kullanımları gibi yönleriyle ele alınmıştır. Çalışma kapsamında Uzunköprü, Muradiye Taş Köprü, II. Beyazıd Köprüsü, Saraçhane Köprüsü ve Fatih Köprüsü incelenmiştir. Araştırmada kentin farklı noktalarında yer alan aynı yüzyıla ait örnekler arasındaki farklı ve ortak özellikler ortaya çıkarılmıştır.

Anahtar Kelimeler: Osmanlı Mimarlığı, Osmanlı Köprüleri, 15. Yüzyıl Edirne Köprüleri, Edirne Taş Köprüleri.

Makale Gönderme Tarihi: 09.10.2019

Makale Kabul Tarihi: 18.01.2020

\section{Önerilen Atıf:}

Akar, I. (2020). 15. Yüzyıl Edirne Taş Köprüleri, Sosyal, Beşeri ve İdari Bilimler Dergisi, 3(1): 1-15.

(c) 2020 Sosyal, Beşerî ve İdari Bilimler Dergisi. 


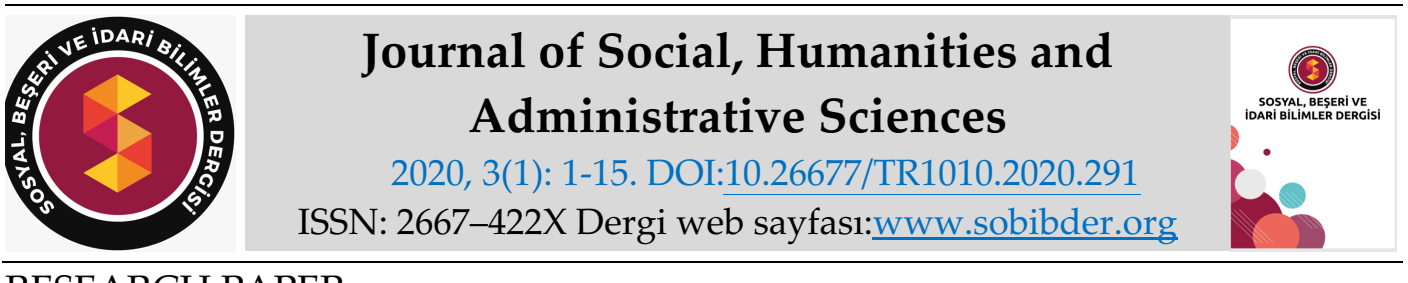

RESEARCH PAPER

15th Century Edirne Stone Bridges

Işı1 AKAR, MSc., Gazi University, Social Sciences Institute, Ankara, e-mail: isillakar@gmail.com ORCID: https://orcid.org/0000-0001-5703-8032

\begin{abstract}
Ottoman Architecture, 14th century to the beginning of the 20th century; The three stylistic activities of the early period (14th-15th century), the Classical Period (15th-17th century) and the Westernization Period (17th-19th century) created one of the richest architectural repertoires in history. Ottoman architecture, which is influential in a wide geography on three continents, has undergone great changes over time and developed itself by synthesizing all the cultures that have ever existed on the lands it dominated. The bridge architecture to be discussed in this article is one of the most important building types of this great architectural tradition. Since the early years of the Empire, numerous bridges have been built in Europe. The Ottoman state was opened to Europe by its bridges over small and large rivers over these lands. In this review; 15th century Edirne bridges which are among the most important bridges built by the Ottomans in this early year are discussed. During the Ottoman period in addition to the construction of new bridges, it is also seen that it was used by repairing the ones from previous periods. This also allows for situations such as the interaction of cultures, the reinterpretation of the architectural features of the work from a different perspective. The areas where bridges are frequently seen are areas that are very rich in waterways. Examples are not only seen on large rivers, but also on smaller and smaller streams in the settlements. Edirne, which was an important position during the Ottoman period, has very important examples of bridge architecture because it is rich in rivers. These examples are not only found in the city center, but also in districts and villages The Edirne bridges, whose dimensions, architectural features and periods when they were built, have survived to this day in good and solid condition. The bridges examined have been handled in terms of the river in which they are located, the number of eyes they have, the arch forms, their understanding of decoration and their current usage. In this research, Uzunköprü, Muradiye Stone Bridge, II. Bayezid Bridge, Saraçhane Bridge and Fatih Bridge were examined.
\end{abstract}

Keywords: Ottoman Bridges, Bridge, Edirne, Edirne Bridges, Edirne, Stone Bridges.

Received: 09.10.2019

Accepted: 18.01 .2020

Suggested Citation:

Akar, I. (2020). 15th Century Edirne Stone Bridges, Journal of Social, Humanities and Administrative Sciences, 3(1): 1-15.

(c) 2020 Sosyal, Beşerî ve İdari Bilimler Dergisi. 


\section{Gíriş}

Trakya Bölgesi'nde yer alan önemli şehirlerimizden biri olan Edirne, tarihinde farklı medeniyetlere ev sahipliği yapmıştır. Bu süreç içerisinde kent “ Orestas, Hadrianapolis, Edrinus " gibi çeşitli isimlerle anılmıştır. ${ }^{1}$ Bulunduğu bölgenin adını içeren Traklar tarafından kurulan şehir zaman içerisinde Roma ve Osmanlı İmparatorluk'larının varlıkları ile gelişerek tarihi ve kültürü oldukça zengin bir kent haline gelmiştir.

Arda, Tunca ve Meriç nehirlerine sahip oluşuyla coğrafi açıdan oldukça elverişli olan Edirne bunlara ek olarak içerdiği dere ve suyollarının fazlalığı nedeniyle Türk köprü mimarisi açısından da önemli bir konuma sahiptir.

Şehir merkezi haricinde ilçelerinde ve köylerinde yer alan köprüler çoğunlukla Osmanlı Dönemi'ne tarihlenseler de şehirde günümüze ulaşmış Roma Dönemi köprüleri de bulunmaktadır. Çalışmada Osmanlı Dönemi köprüleri içerisinden 15. yüzyıla tarihlenen örnekler ele alınmıştır.

\section{YÜZYIL EDİRNE KÖPRÜLERI}

Edirne, şehir merkezi ve ilçelerinde, bağlantı köprüleri de dâhil olmak üzere toplam 31 adet köprüye sahiptir. ${ }^{2}$ Çeşitli dönemlere tarihlenen bu köprülerin çoğunluğu Osmanlı Dönemi'ne aitken aralarında Roma Dönemi'nde inşa edilen, Osmanlı tarafından kullanılan ve günümüze ulaştırılan köprüler de bulunmaktadır.

$\mathrm{Bu}$ araştırmanın konusu olarak ele alınan beş adet 15. yüzyıl Edirne Köprüsü örneği tamamen Osmanlı kökenli köprülerdir. Bu dönem örnekleri şehir merkezinde yer almaktadır.

Edirne köprülerinin tamamında görülen genel malzeme olan taş 15. yüzyıl köprülerinin de ana malzemesidir, ele alınan eserler taş malzeme ile inşa edilmiş olarak karşımıza çıkar.

Uzunköprü, Saraçhane Köprüsü gibi süsleme ögelerine yer verilen örnekler görülmekle birlikte Muradiye Taş köprü gibi oldukça sade ve süslemesiz bir anlayışla yapılan yapılar da vardır. İncelenen köprüler Edirne Kültür Varlıklarını Koruma Bölge Kurulu tarafından başlıkları altında yer verilen tarih ve sayılı kararlarla tescillenmiş, günümüze oldukça sağlam durumlarda ulaşmışlardır. Muradiye Taş Köprü örneği dışında yaya ve araç kullanımına uygun durumdadirlar.

Bu köprülerin bakım ve onarımından sorumlu olan kuruluş Karayolları Genel Müdürlüğü'dür. Konu hakkında yapılacak araştırma ve çalışmalarda Edirne Taşınmaz Kültür Varlıkları Envanteri, Edirne Kültür Varlıklarını Koruma Bölge Kurulu tescil kararları ve Karayolları Genel Müdürlüğ̈̈'ne ait yayınlar temel kaynak olarak kullanılmıştır.

\footnotetext{
1 Tuğlacı, P. "Osmanlı Şehirleri" s.102

2 II. Beyazıd, Fatih, Kanuni, Gazi Mihal,Yalnızgöz, Saraçhane, Yıldırım, Meriç, Tunca, Kazan, Sefer Şah, Uzunköprü, Sarıkız, Kurtdere, Elçili, Mercan I, Mercan II, Enez Manastır, Kemalköy, Saraçhane Ek, Yalnızgöz - Beyazıd Bağlantı, Muradiye, İzzetiye, Altıntaş, Üç Şehitler, Işıklı, Öksüzdere, Nalbur, Çamlıca, Kılıçköy, Naifa Köprüleri
} 


\section{Fatih Köprüsü}

Edirne Kültür Varlıklarını Koruma Bölge Kurulu tarafından 14.02.1980 tarihinde 11789 sayılı karar ile tescillenen Fatih Köprüsü Bönce, Cephanelik, Süvari gibi isimlerle de anılır. Edirne Sarayiçi'nde bulunan köprü Saray-ı Cedid-i Amire olarak adlandırılan Edirne Saray kompleksi içerisinde yer almaktadır. Fatih Sultan Mehmet tarafından saray yapımı esnasında yaptırılmıştır. ${ }^{3}$ Yapı 15. yüzyıl ortalarına aittir, 1452 ( H. 856 M. 1452) yılına tarihlenir.

Tunca Nehri üzerinde bulunan Fatih Köprüsü şehir merkezinde yer alan önemli eserler arasındadır. Edirne'de yer alan diğer köprülerle malzeme bakımından ortak özellik gösterir, düzgün kesme taştan inşa edilmiştir. Mimari özellikleri incelendiğinde 3 kemer ve sel yaranlarının üzerinde bulunan 2 tahliye gözünden oluştuğu görülür. Köprüde yer alan kemerler sivri forma sahiptirler.

Orta kemeri yanlarda bulunanlardan daha uzun ve geniş oluşturulduğu için köprü eğimli bir yapıya sahiptir. ${ }^{4}$ Uzunluğu 34,20 genişliği 4.56 metre olan köprünün en büyük kemer açılığ 8.20 diğer kemer açıklıkları ise 6.10 metredir. ${ }^{5}$

Saray alanı içerisinde yer alması nedeniyle etrafında Matbah-ı Amire, Kum Kasrı Hamamı gibi önemli mimari eserler bulunur. Bu dururum örnek olabilecek önemli mimari yapılardan biri olan Adalet Kasrı köprünün hemen önünde yer almaktadır. Fatih Köprüsü'nün kemer ayaklarında yer alan sel yaranların memba yönünde olanları üçgen forma sahipken mansap yönünde yer alanlar sivri ucu pahlanmış üçgen formundadırlar. Yapının mimari bilinmemektedir. Köprüde herhangi bir süsleme ögesi, kitabe ve seyir köşkü yer almamaktadır. Geçirdiği restorasyonların da etkisiyle köprüde herhangi bir deformasyon görülmemekte, günümüzde oldukça sağlam bir biçimde kullanımda bulunmaktadır.

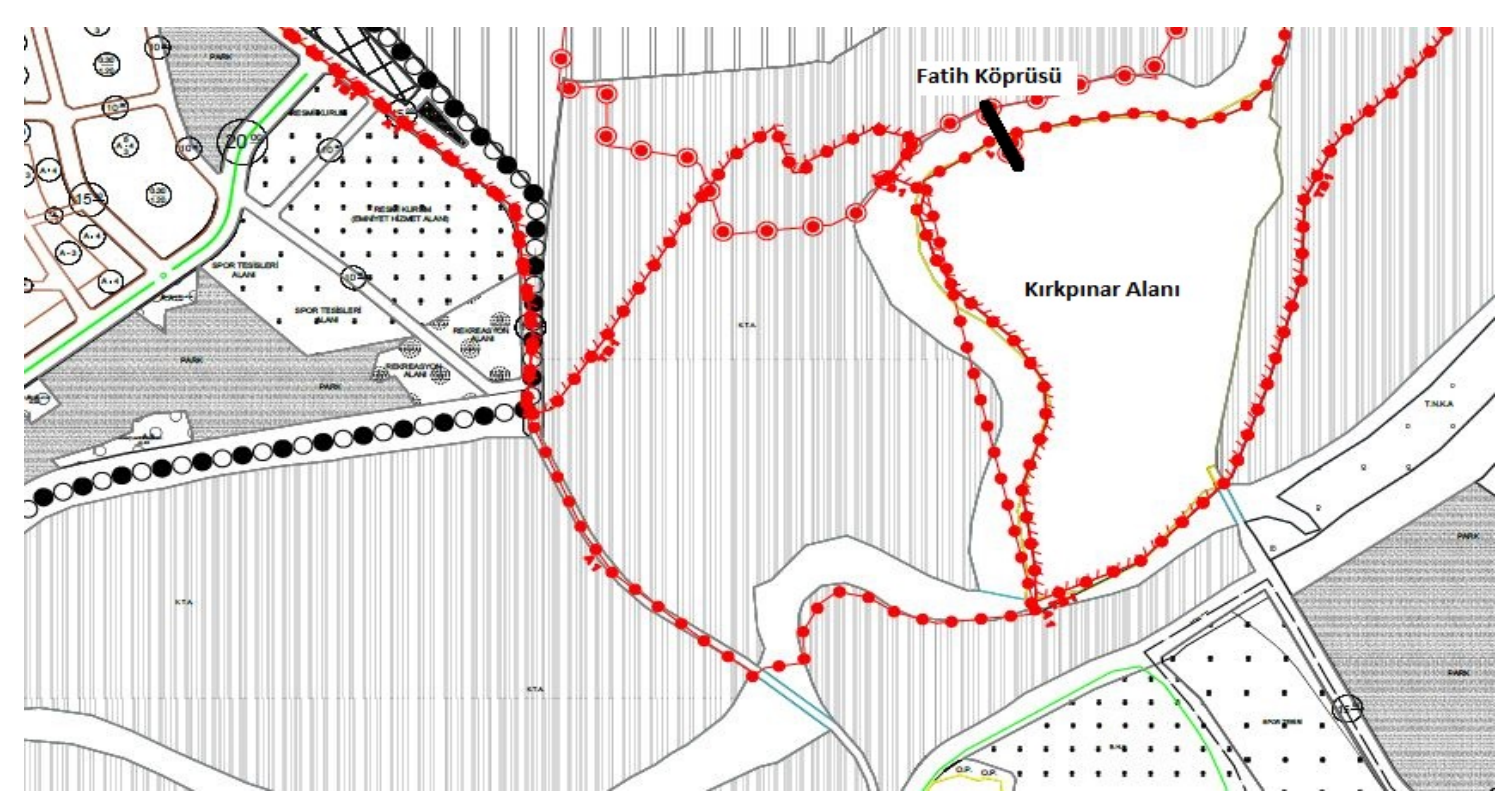

Görsel 1: Edirne Fatih Köprüsü. Edirne Belediyesi İmar ve Şehircilik Müdürlüğü Vaziyet Planı Detay (2019)

\footnotetext{
3 Tunç, G. "Taş Köprülerimiz” s.77

4 Pekin, F., Yılmaz H. F. “Türkiye'nin Kültür Mirası 100 Köprü” s.74

${ }^{5}$ Çulpan, C. “Türk Taş Köprüleri ( Ortaçağdan Osmanlı Devri Sonuna Kadar )” s.109
} 


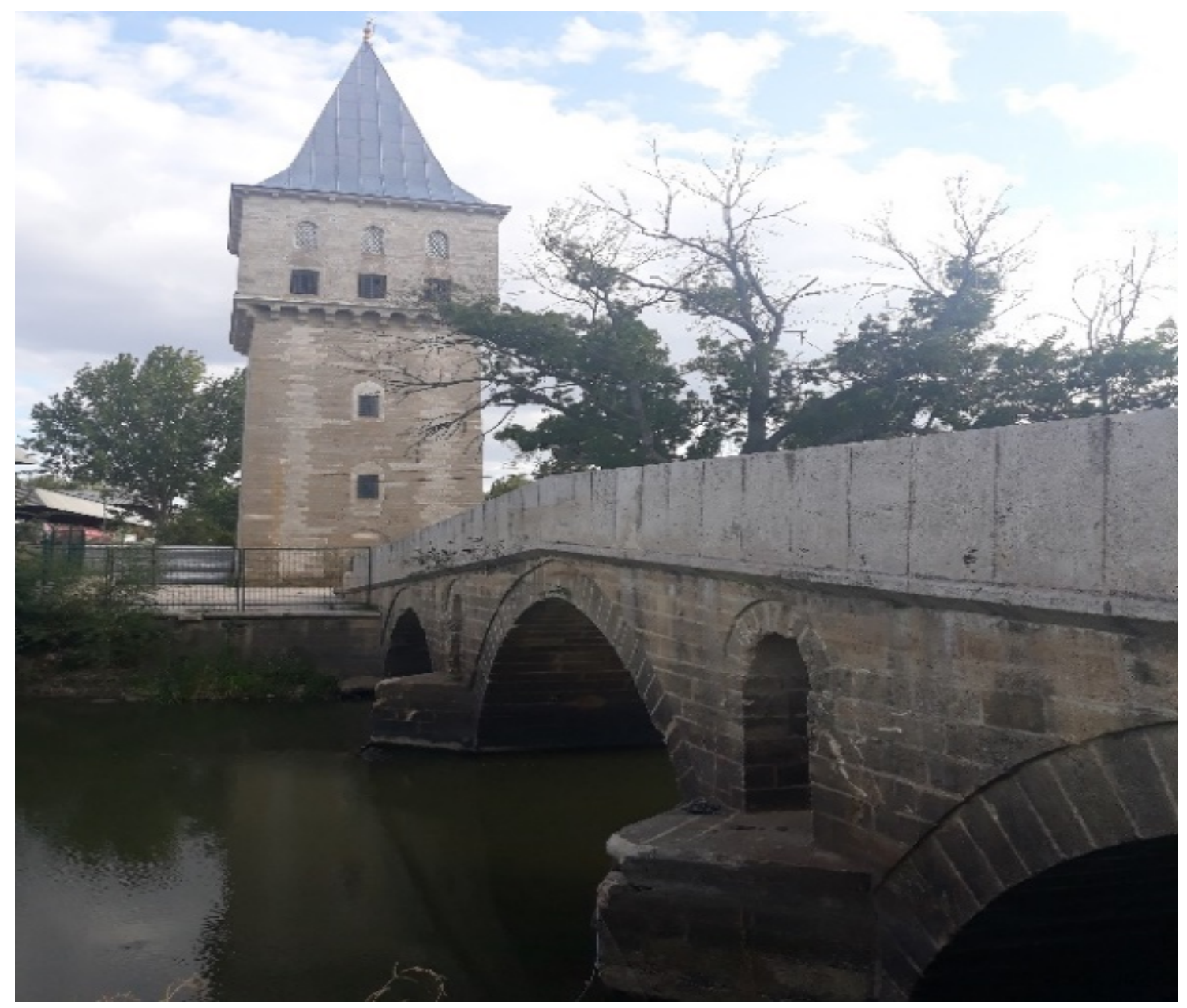

Görsel 2: Edirne Fatih Köprüsü. Akar, 2018.

\section{Muradiye - Taş Köprü}

Köprü Edirne Kültür Varlıklarını Koruma Bölge Kurulu tarafından 05.11. 2012 tarih ve 669 sayılı karar ile tescillenmiştir. Muradiye Köprüsü ya da Taş Köprü adları ile anılır. Edirne şehir merkezi içerisinde Muradiye Mahallesi Taş Köprü sokakta yer alır. Yapılışında üzerine oluşturulduğu suyolunun adı bilinmemektedir.

15. Yüzyılda Muradiye Cami'si ile birlikte inşa edildiği düşünülen köprü günümüzde evler arasında kalarak özgün işlevini yitirmiştir. Bulunduğu alandaki evlere bitişik duruma gelmiş olması nedeniyle hasar almaya oldukça açık haldedir. Kenarlarında korkuluklar görülmez. Her iki yönü de konutlara çıktığından köprü üzerinde günümüzde ulaşım sağlanamamaktadır. Tek göze sahip bir köprüdür Yuvarlak kemerli köprünün kemer örgüsünde düzgün kesme taş, kalan bölümlerde moloz taş kullanılmıştır. Herhangi bir süsleme ögesine rastlanmaz. Köprünün kitabesi yoktur. 


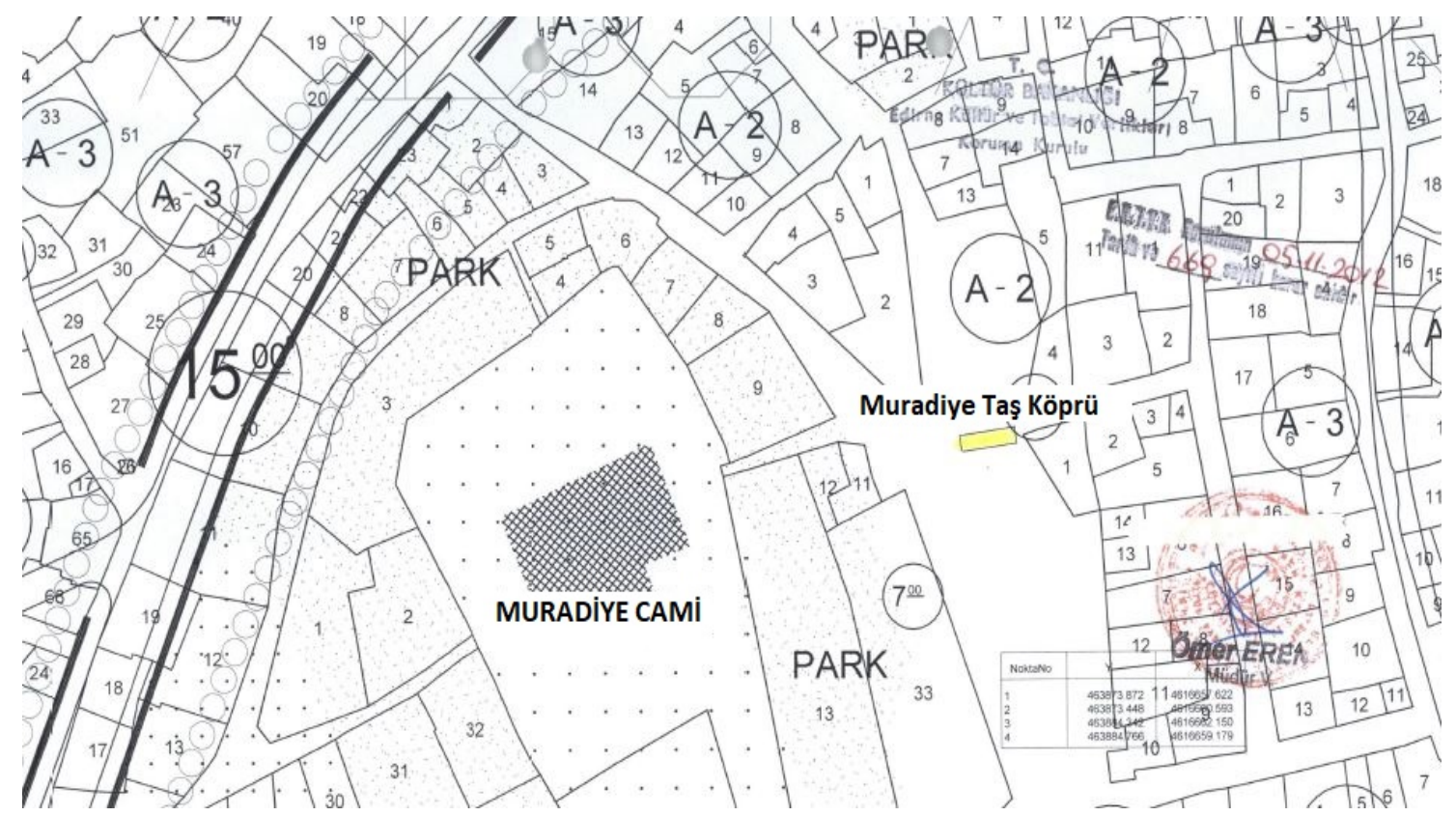

Görsel 3: Edirne Muradiye Mahallesi Taş Köprü.05.11.2012 tarih 669 sayılı K.V.K.B.K kararı (2012)

Köprü altı sadece yaya geçişine olanak veren durumdadır. Yerleşim yeri arasında kalmasından dolayı köprüde doğal ve insan etkilerinden kaynaklı deformasyon mevcuttur. Ayrıca günümüzde köprüde çimento kullanılarak yapıldığı anlaşılan derzler görülmektedir. ${ }^{6}$

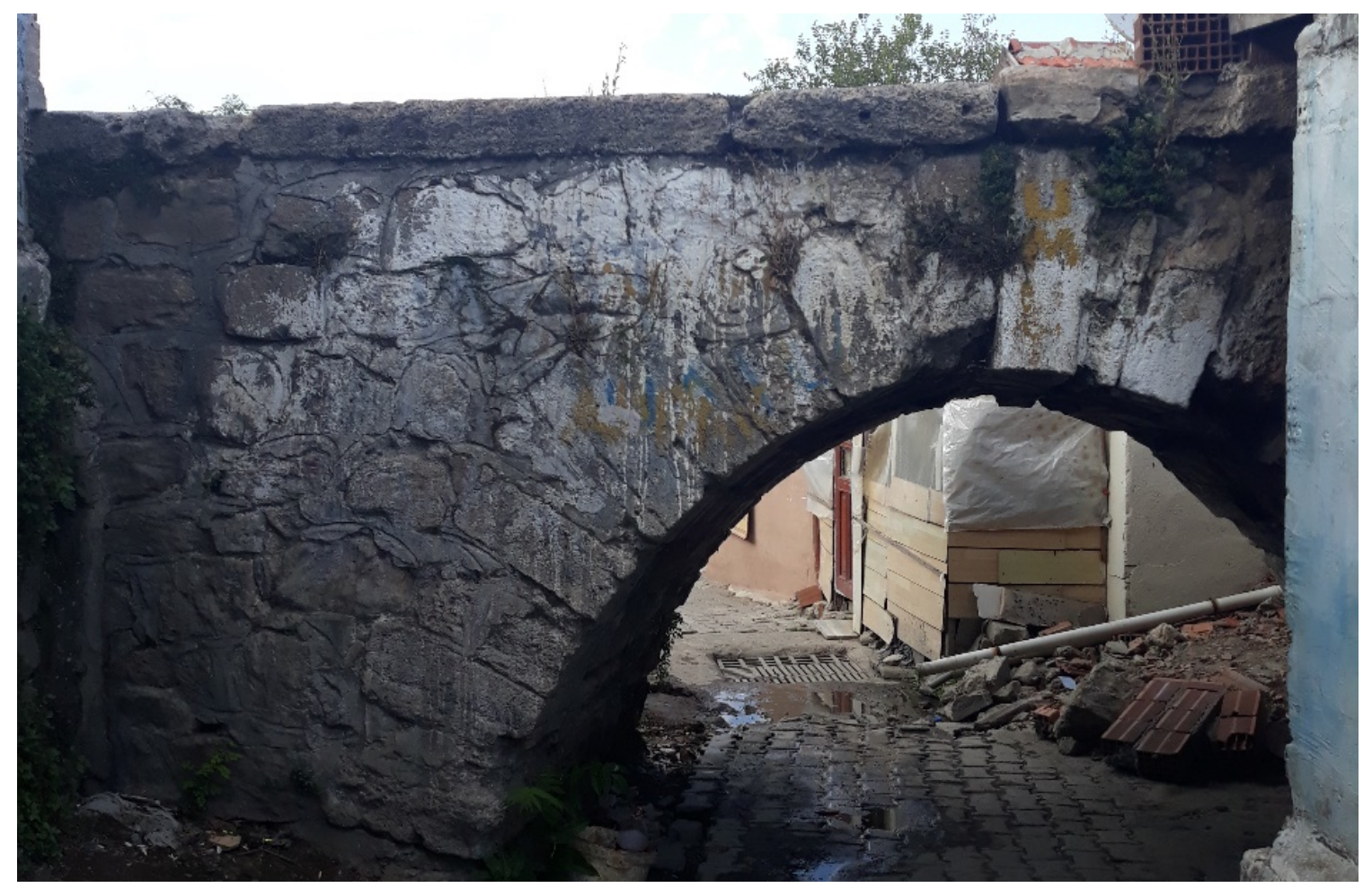

Görsel 4: Edirne Taş Köprü. Akar, 2018.

${ }^{6}$ Edirne Kültür Varlıklarını Koruma Bölge Kurulu 05.11.2012 Tarihli 669 Sayılı Kararı 


\section{Beyazıd Köprüsü}

Köprü Edirne Kültür Varlıklarını Koruma Bölge Kurulu tarafından 14.03.1980 tarih ve 11789 sayılı kararı ile tescillenmiştir. Yeni İmaret, Beyezıd Veli Köprüsü gibi isimlerle de anılmaktadır. Yeni İmaret Mahallesi'nde yer alan köprü 15.yüzyılın sonlarına tarihlenmektedir. Yapım tarihi $1488^{\prime}$ dir. II. Beyazıd'ın emriyle Mimar Hayreddin tarafından Tunca Nehri üzerine inşa edilmiştir.7 II. Beyazıd Külliyesi'nin bir parçası olan köprü külliye ile şehir arasında bir bağlantı görevi görmektedir. 126.5 metre uzunluğundadır. ${ }^{8}$

Köprü üzerinde kitabe yer almaz. 6 adet gözden meydana gelen II. Beyazıd Köprüsü sivri kemer formuna sahiptir. Günümüzde üç gözünden su akmaktadır. Diğer gözler toprak kısım üzerinde yer alır. Yağışlar ile birlikte nehir yatağının genişlemesi sonucu köprünün kullanımda olan göz sayısı artış gösterir. Üzerinde herhangi bir süsleme ögesine rastlanmayan köprü oldukça sade bir biçimde inşa edilmiştir.

II. Beyazıd köprüsü, Yalnızgöz ve aralarında bulunan bağlantı köprüsü ile birlikte Yeni İmaret mahallesini kent merkezine bağlar.

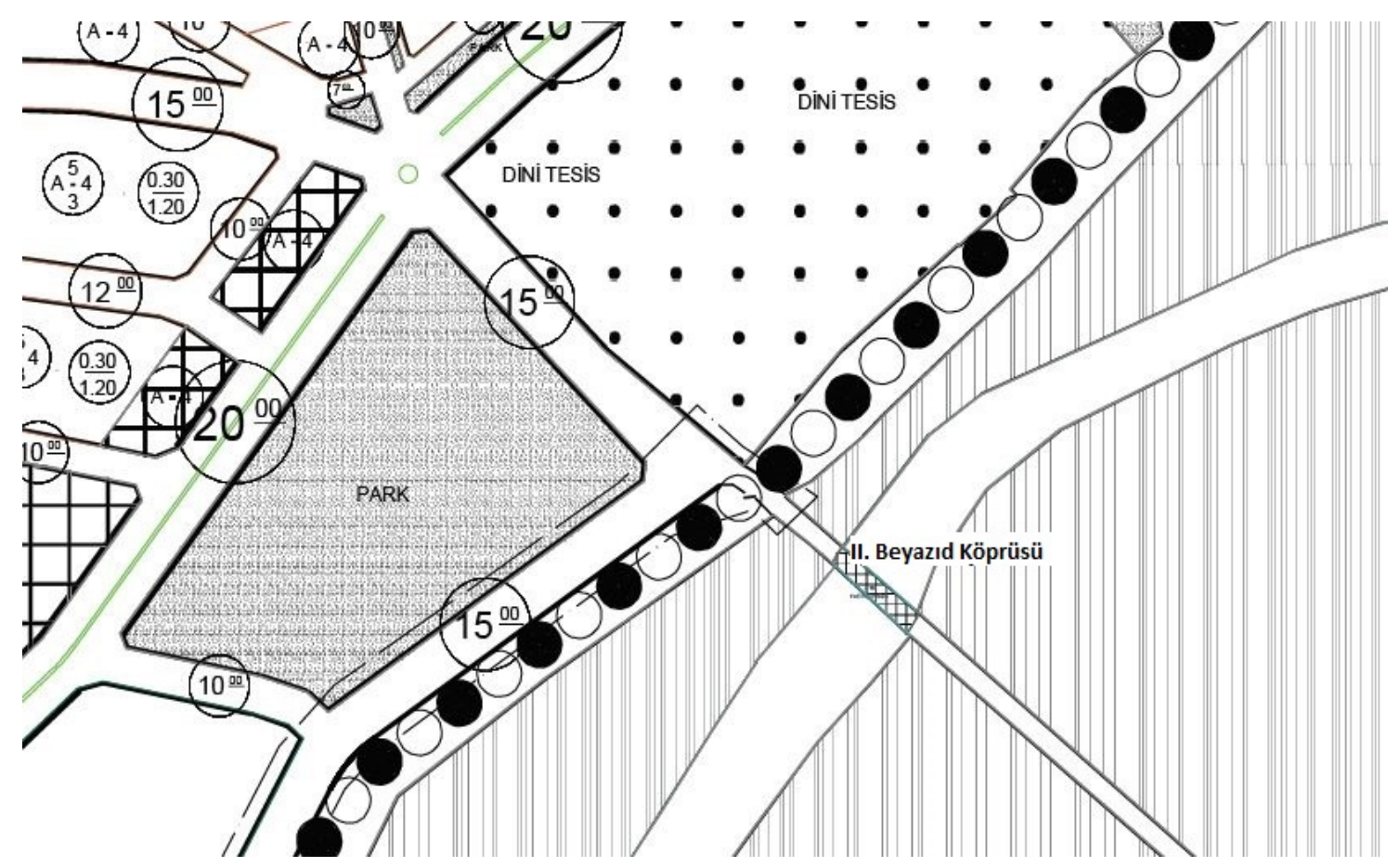

Görsel 5: Edirne II. Beyazıd Köprüsü. Edirne Belediyesi İmar ve Şehircilik Müdürlüğü Vaziyet Planı Detay (2019)

\footnotetext{
${ }^{7}$ Edirne Taşınmaz Kültür Varlıkları Envanteri s. 198

8 Tunç, G. “Taş Köprülerimiz” s. 27
} 


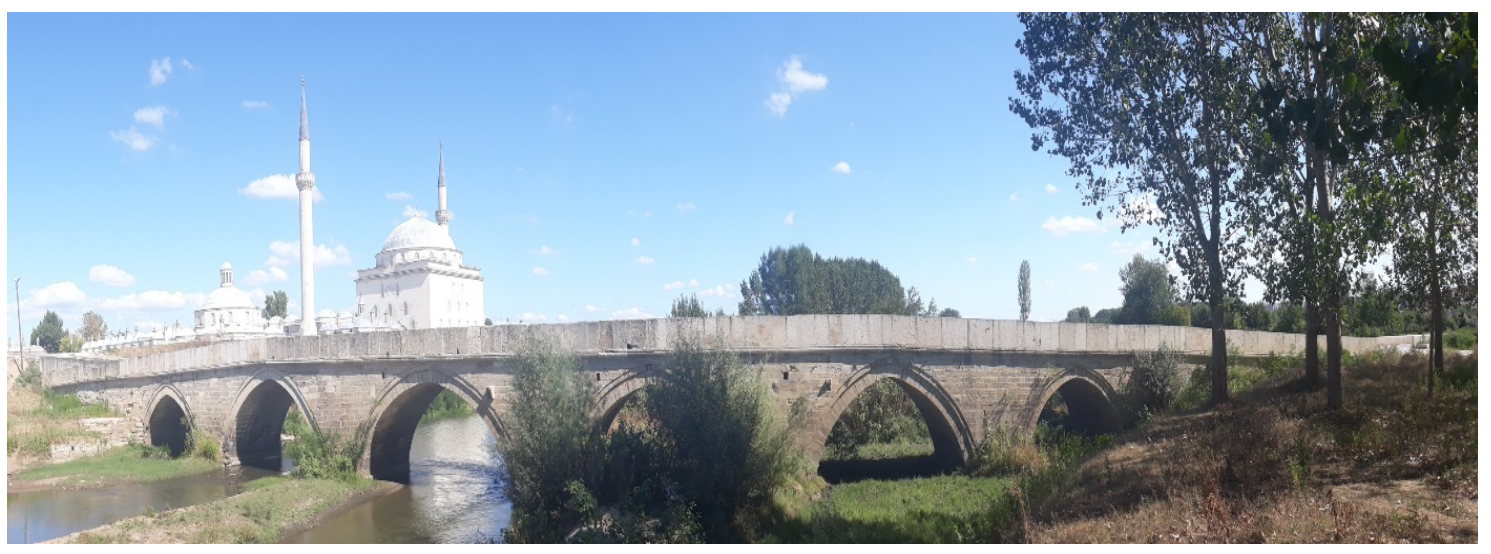

Görsel 6: Edirne II. Beyazıd Köprüsü Genel Görünüm. Akar, 2018.

Köprüde, Yalnız Göz Köprüsü'ne doğru olan tarafta yuvarlak kemer formuna sahip iki adet tahliye kemeri yer alır. Bu alan su seviyesinin yüksek olmayışından dolayı bitkiler ve toprakla kaplıdır. Köprü günümüze oldukça sağlam bir durumda ulaşmıştır. Fakat suların çekildiği alanlarda ortaya çıkan yoğun bitki oluşumunun köprü üzerinde yıpranmalara neden olduğu görülmektedir. Günümüzde köprüden hem araç hem yaya geçişi sağlanır.

\section{Uzunköprü}

Köprü Edirne Kültür Varlıklarını Koruma Bölge Kurulu Tarafından 14.10.1978 tarih 10729 sayılı kararı ile tescillenmiştir. Ergene Köprüsü adı ile de anılır. Köprü Uzunköprü ilçesi girişinde başlayıp yerleşim yeri başlangıcına kadar uzanmaktadır. Ergene Nehri üzerinde yer alır.

II. Murat tarafından nehirden geçişte güvenliği sağlamak amacıyla yaptırılmış sonrasında ise etrafında yerleşim alanı kurularak bir kasaba oluşturulmasına imkân sağlamıştır. Mimarı Hacı İvaz, nakkaşı ise İlyas Ali Usta'dır. ${ }^{9}$ Uzunluğu 1266, eni 5.90 metredir. 174 gözden meydana gelmektedir.

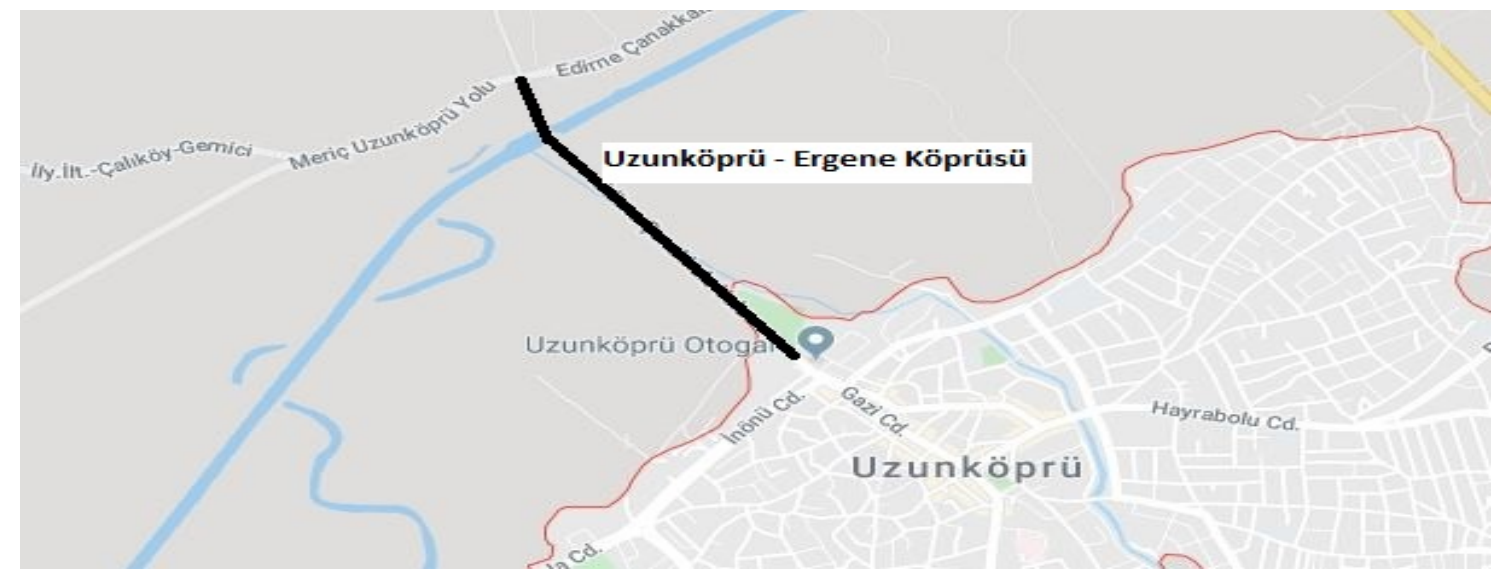

Görsel 7: Uzunköprü Konum. Google Maps (2019)

9 Tunç, G. “Taş Köprülerimiz” s. 193 


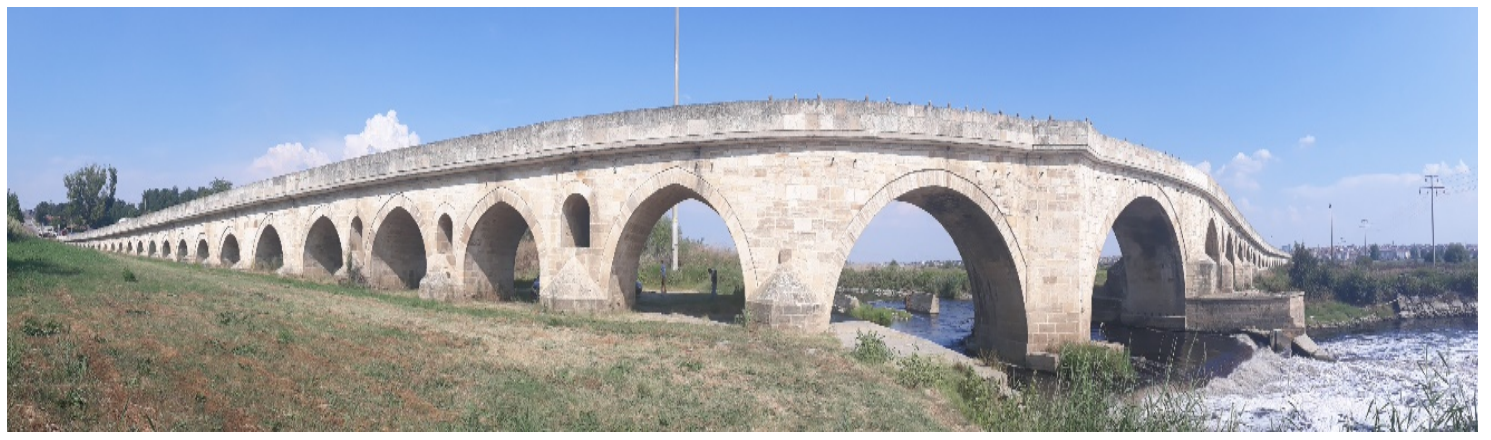

Görsel 8: Uzunköprü. Akar, 2018.

Köprü, uzunluğu ve sahip olduğu kemer sayısının fazla olması nedeniyle kemer kullanımı konusunda çeşitliliğe olanak sağlamıştır. Sivri ve yuvarlak kemer formları köprüde bir arada kullanılmıştır. Günümüzde normal mevsim şartlarında sadece 2 gözden su akışı görülür.

Yağışlar ve nehrin doluluk oranına göre köprünün kullanılan göz sayısı değişmektedir. Bu çalışmada incelenen diğer örneklerin aksine süsleme yönünden oldukça zengin özelliklere sahip olan köprüde bitkisel, geometrik ve hayvansal bezeme örneklerine rastlanmaktadır. Taş kabartma şeklinde olan bu süslemeler genellikle kemerlerin kilit taşlarında, kemer ayakları üzerinde ya da tahliye gözlerinde yer almaktadır. Bu süslemelerde alçak kabartma ve yüksek kabartma tekniklerinin birlikte kullanıldığı görülür.
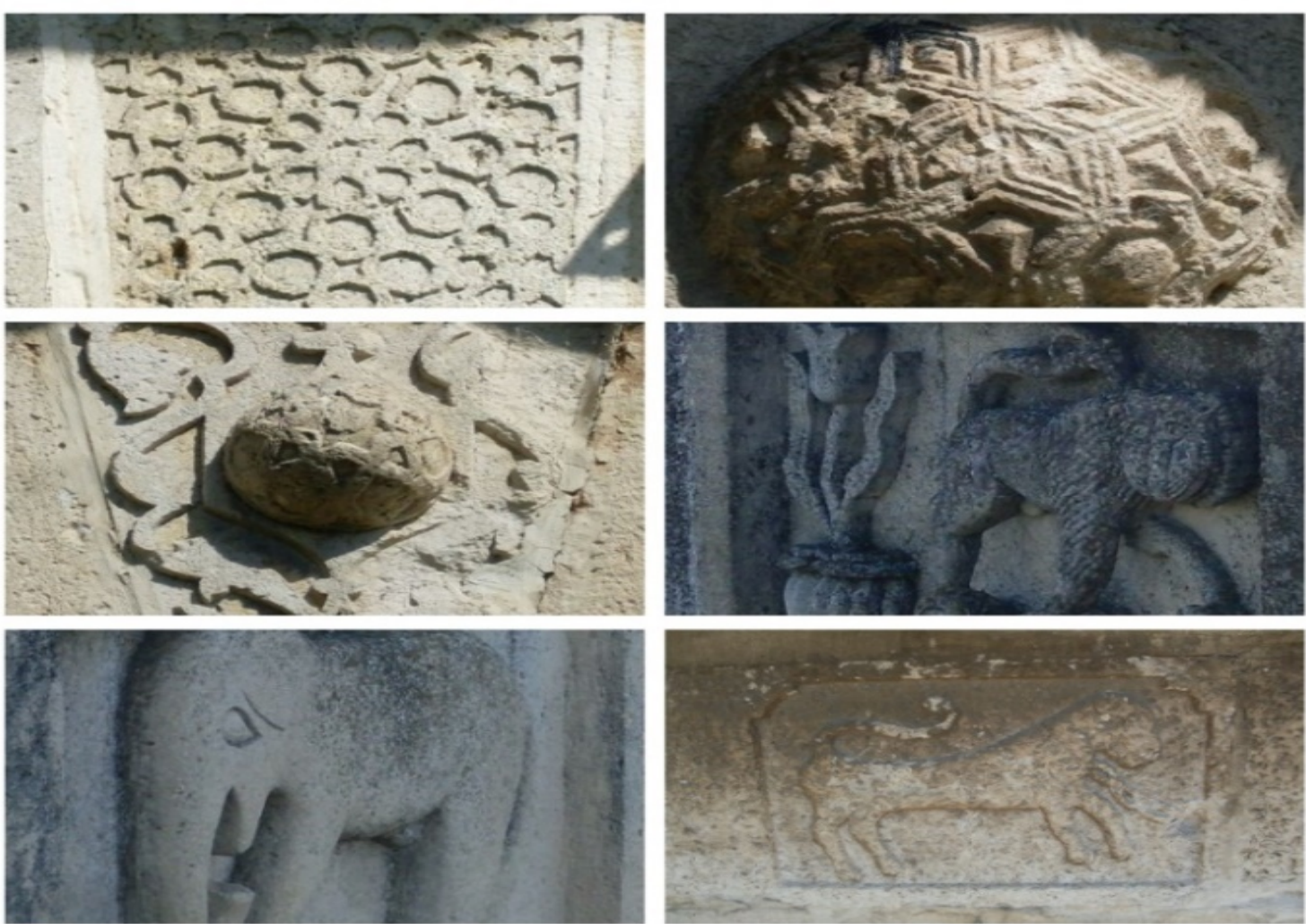

Görsel 9: Uzunköprü Taş Süsleme Detay. Akar, 2018. 
Köprünün iki kitabesinden biri 1922 yılında Yunan işgali sırasında tamamen kazınmıştır. ${ }^{10}$ Kalan diğer köprü kitabesi II. Abdülhamit zamanındaki onarım sırasında Gazi Mihal Bey veya Belediye Parkı çeşmesi denilen çeşme üzerine konulmuştur. ${ }^{11}$ Cevdet Çulpan 1968 yılında yayınlanan makalesinde bu durumdan “ Uzunköprü'de, II. Murad devri (H. 847 , M. 1443-44) eseri olan 174 gözlü ve 1392 metre boyundaki Uzunköprü'nün kitabesi, II. Hamid devri onarımı sırasında , kasaba içinde Gazi Mahmut Bey veya Belediye Parkı Çeşmesi diye anılan çeşme üzerine nakledilmiş olup hala oradadır." şeklinde bahsetmektedir. ${ }^{12}$

Kırsal alanda yer alması dolayısıyla tarım araçları ve ağır vasıtaların geçişlerinden rahat kullanılamayan ve deforme olan Uzunköprü'ye bu tip araçların kullanımı için paralel, altarnatif bir köprü yapılmıştır.

$\mathrm{Bu}$ durum köprünün daha rahat kullanılmasına ve daha az hasar alma riskine imkan vermektedir. Uzunköprü günümüze çoğunlukla iyi durumda ulaşsa da, köprü üzerinde define arama çalışmalarının yapıldığı taşlarda yer alan tahrip izlerinden görülmektedir.

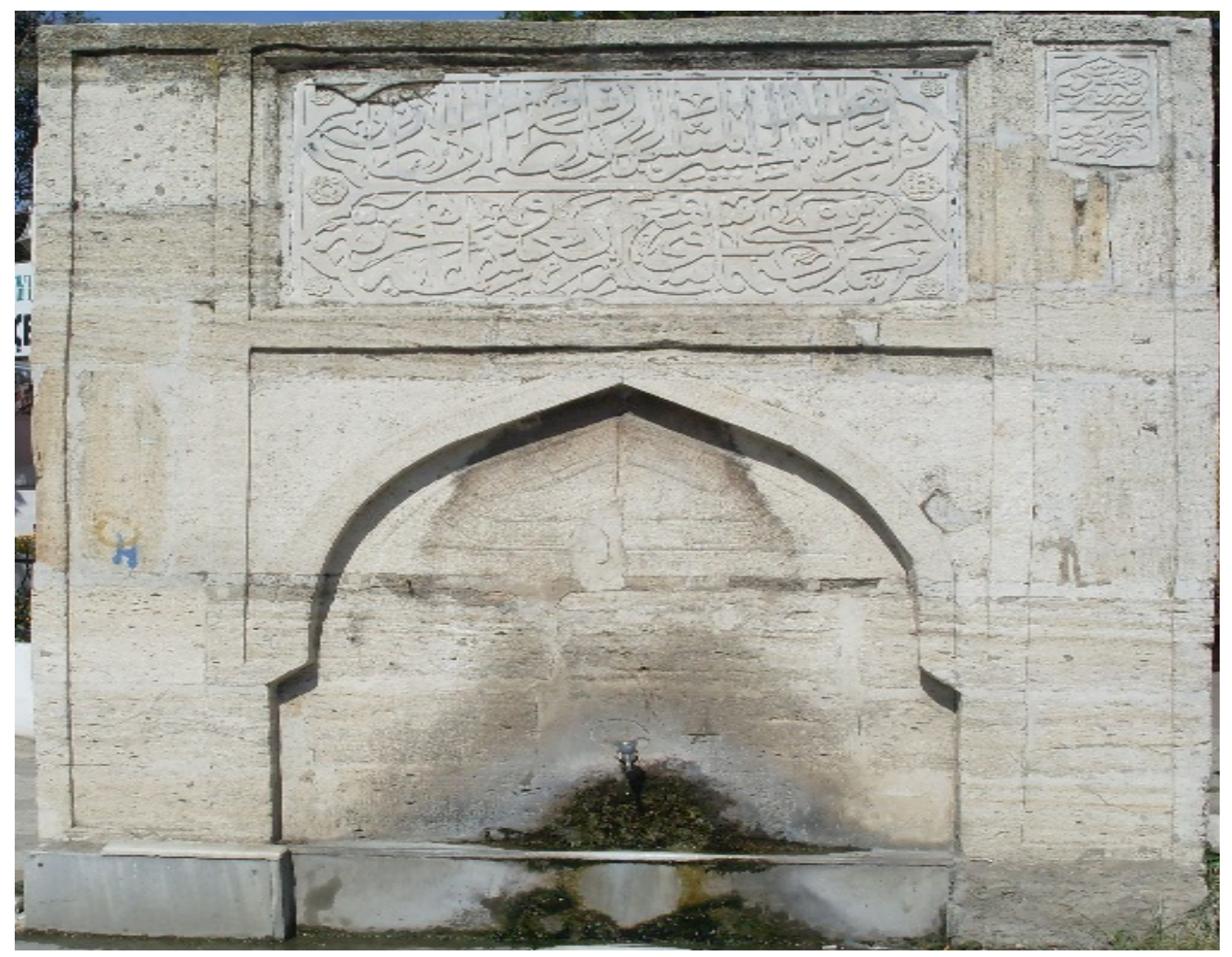

Görsel 10: Uzunköprü Belediye Çeşmesi Üzerinde Yer Alan Kitabe. Akar, 2018.

\footnotetext{
${ }^{10}$ Pekin, F., Yılmaz H. F. “Türkiye'nin Kültür Mirası 100 Köprü” s.82

11 Tunç, G. “Taş Köprülerimiz” s.192

${ }^{12}$ Çulpan, C. "Köprülerde Tarih Köşkleri” s.34
} 


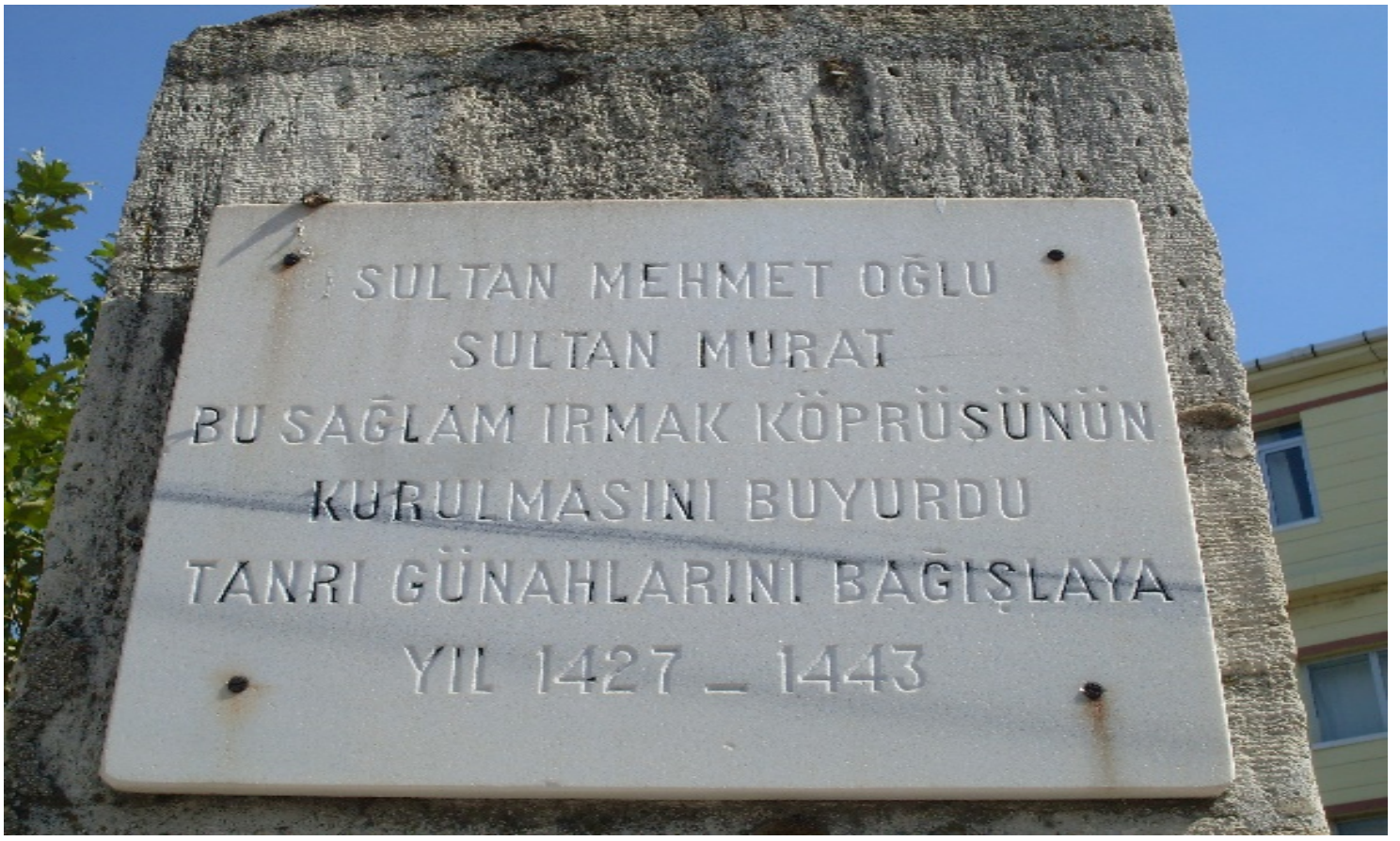

Görsel 11: Uzunköprü Belediye Çeşmesi Üzerinde Yer Alan Kitabe. Akar, 2018.

\section{Saraçhane Köprüsü}

Köprü Edirne Kültür Varlıklarını Koruma Bölge Kurulu tarafından 14.03 .1980 tarih 11789 sayılı kararı ile tescillenmiştir. Banisi dolayısıyla Şehabettin Paşa Köprüsü olarak da bilinir. Sultan II. Murat ulemasından olan Şehabettin Paşa'nın, bu köprü haricinde Filibe'de cami, imaret, kervansaray gibi eserlerinin olduğu da bilinmektedir. ${ }^{13}$ Köprü yaptıranının adını taşısa da bölgedeki yaygın kullanımında, bitişiğinde bulunan Saraçhane Mahallesi'nin adıyla anılır. ${ }^{14}$

Yeni İmaret mahallesinde yer alan köprü 1451 yılında II. Murat ve Fatih Sultan Mehmet dönemlerinde vezirlik yapan Şihabettin Paşa tarafından yaptırılmışır. Tunca Nehri üzerinde bulunur. Boyu 120 metre genişliği 5 metredir. ${ }^{15}$ Saraçhane köprüsü 10 gözden meydana gelmektedir. ${ }^{16}$ Kemerleri yuvarlak forma sahiptir.

13 Tunç, G. “Taş Köprülerimiz” s.159

${ }^{14}$ Pekin, F., Yılmaz H. F. “Türkiye'nin Kültür Mirası 100 Köprü” s.80

${ }^{15}$ Çulpan, C. "Türk Taş Köprüleri ( Ortaçağdan Osmanlı Devri Sonuna Kadar )" s.108

16 Tunç, G. "Taş Köprülerimiz" adlı kitabında köprünün aslında 12 göz olarak inşa edildiğini, zaman içerisinde iki başta bulunan gözlerin toprak altında kalarak yok olduklarını belirtmektedir. 


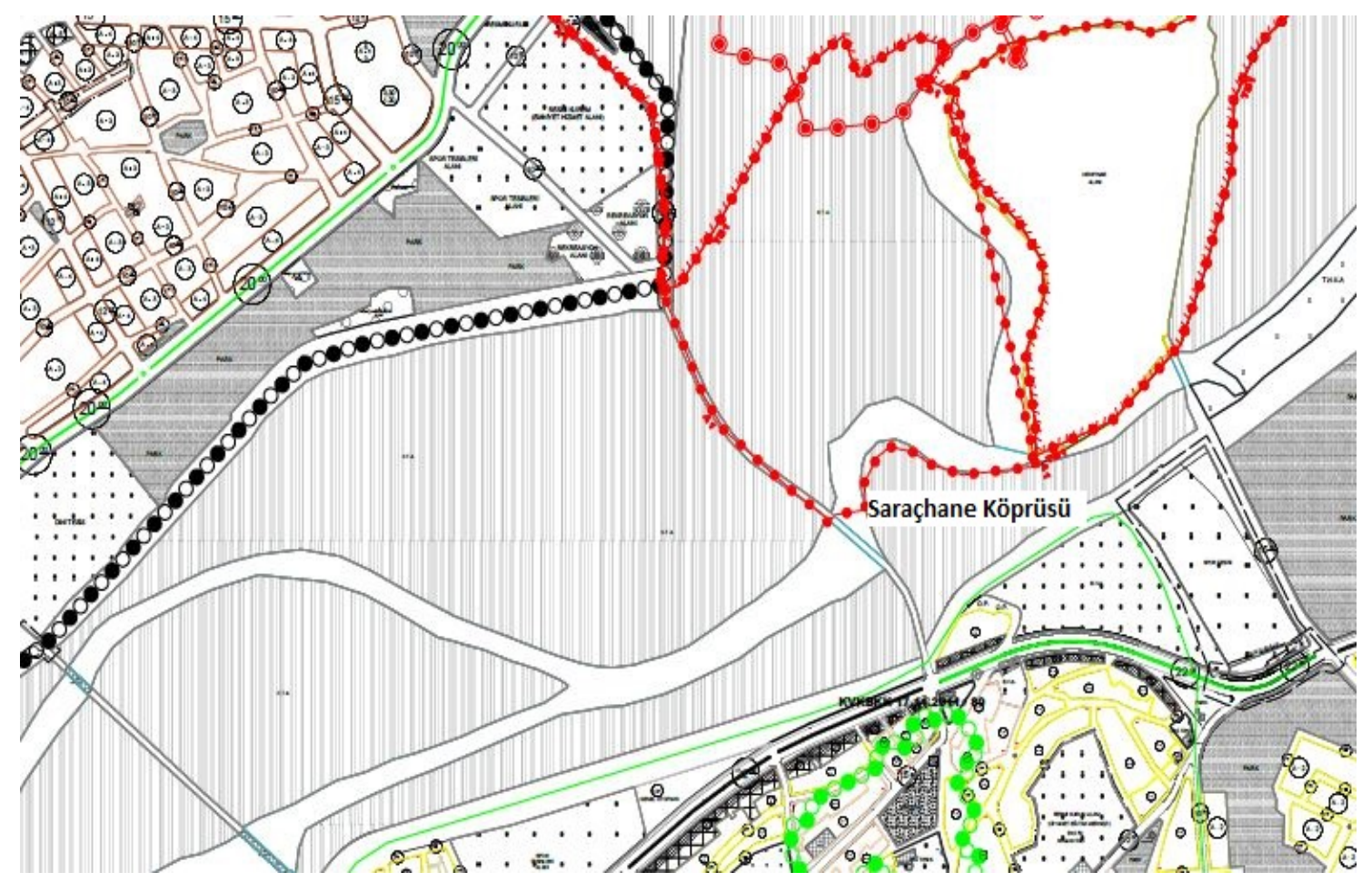

Görsel 12: Edirne Saraçhane Köprüsü. Edirne Belediyesi İmar ve Şehircilik Müdürlüğü Vaziyet Planı Detay (2019)

Köprünün orta noktasında bir kitabe köşkü yer alır. Bu kısımda onarım kitabesi bulunur. Asıl kitabesi 4 satır halinde ve 1451 tarihini taşımaktadır. ${ }^{17}$ Köşkün en üst kısmında yer alan süsleme şeridinde bitkisel süslemeye yer verilmiş, şerit boyunca 25, uç kısımlarda 2 adet yarım halde ve şeridin üst orta noktasında 1 adet büyük halde palmet motifi kullanılmıştır. Kemer örgüsü almaşık teknik ile oluşturulmuş kilit taşında ise yine bitkisel bezemeye sahip bir rozet kullanılmıştır.

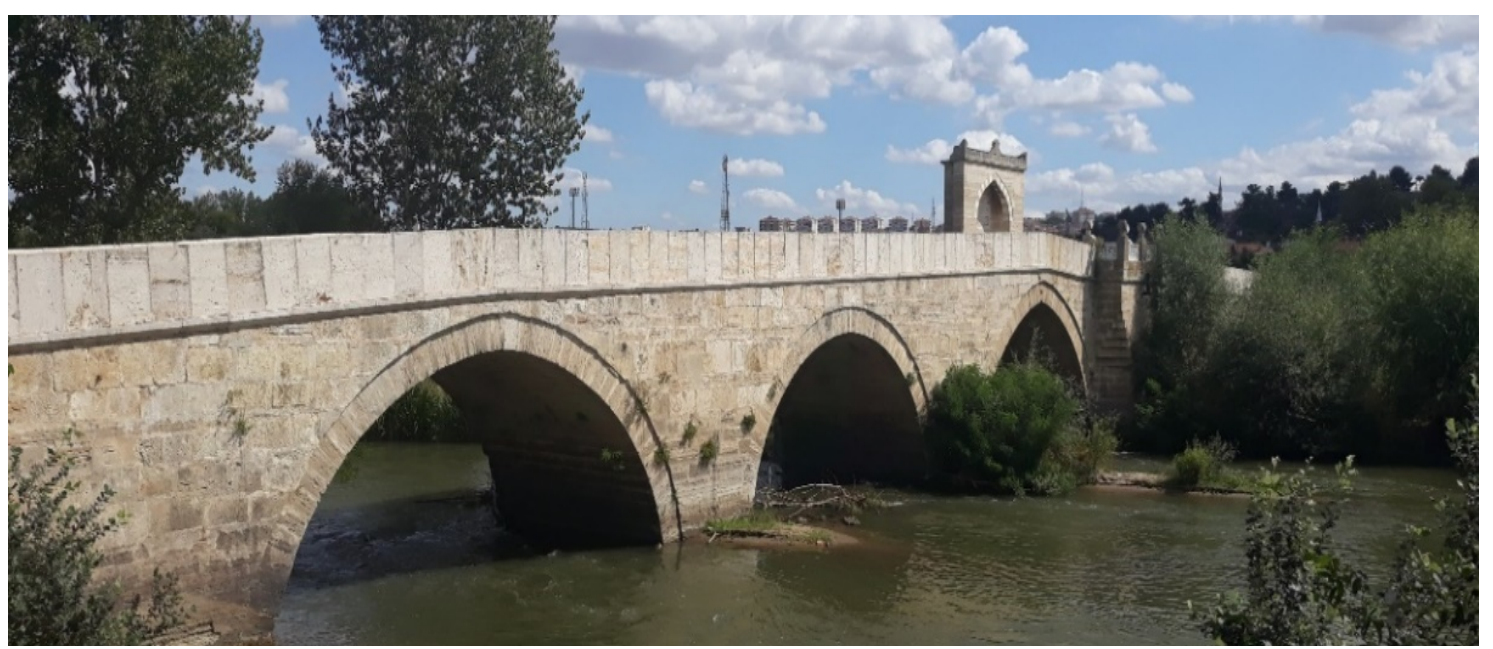

Görsel 13: Saraçhane Köprüsü Genel Görünüm. Akar, 2018.

${ }_{17}$ Tuğlacı, P. “Osmanlı Şehirleri” s.109 
Günümüzde bu köşk kısmında bulunan kitabe 1702 yılında II. Mustafa döneminde yapılan onarıma aittir. 5 Satır ve 10 bölümden oluşan kitabenin etrafı birbirlerine birleşik palmetlerden oluşan bir şerit ile çevrilidir.

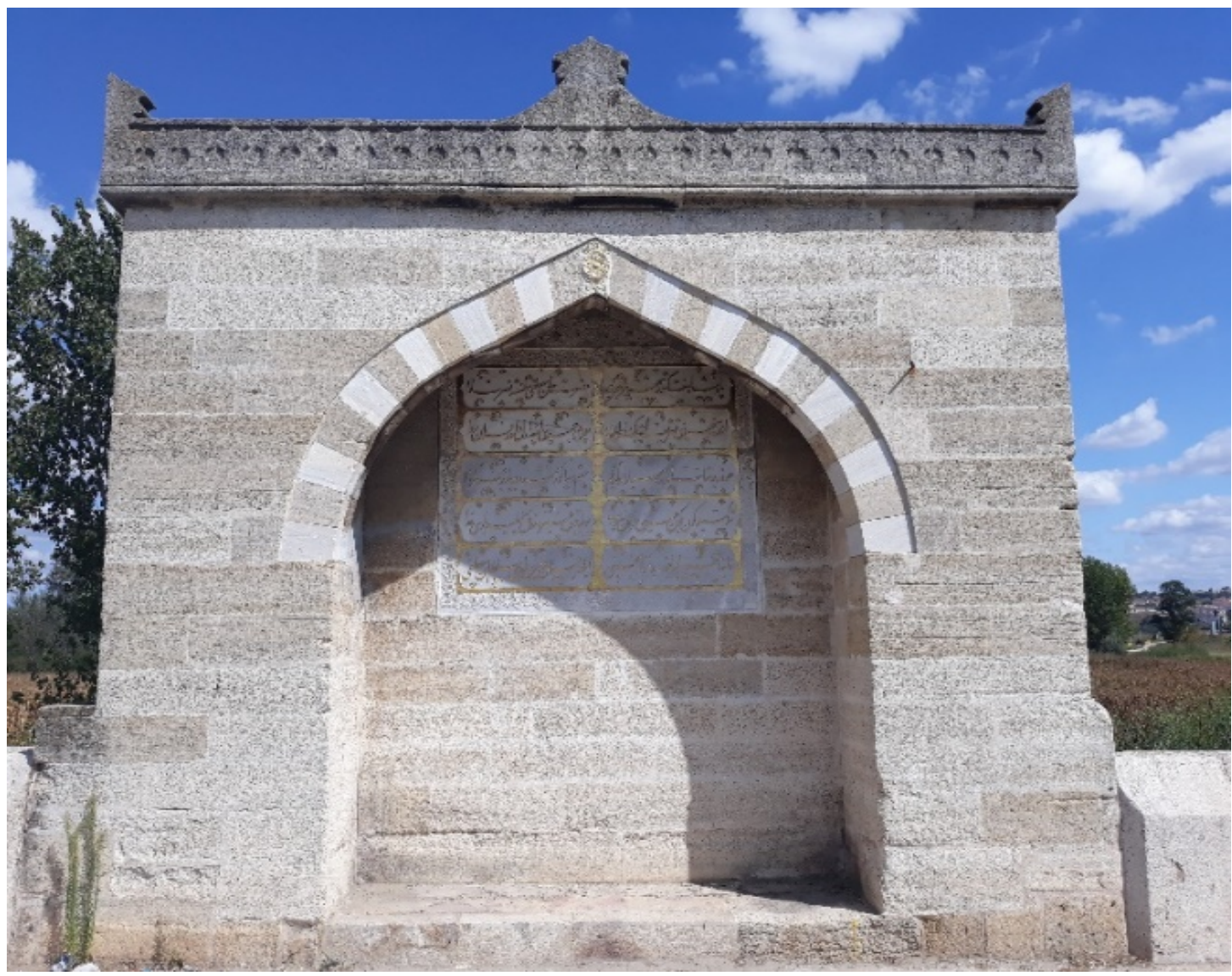

Görsel 14: Saraçhane Köprüsü Kitabe Köşkü. Akar, 2018.

Onartm Kitabesi:

Padişahı Hefr kişver şehriyari behr-u-ber

Hazreti Han Mustafa Şahinşehi Nusret Liva

Edirne şehrine teşrif idecek emreyledi

Çün bu cisri yapmağa ol daveri ferman reva

Hamdü-lillah bir metanet üzre bünyad oldu kim

Çeşmi dünya görmemiştir böyle bir muhkem bina

Şevketiyle günbegün ömrünü efzun eyleyip

Böyle çok hayra muvaffak eyleye bari Hüda

Faika tekmil olunca didiler tarihini (69)

Eyledi ferman bu cisri yaptı Sultan Mustafa

$113-1702^{18}$

${ }^{18}$ Oral, O. "Edirne Türk Tarih Vesikalarından Kitabeler" s.158 
Köşkün tam karşısında yer alan dışarıya çıkıntı yapılarak oluşturulmuş balkon formunun korkuluk kısımları ajur tekniği ile oluşturulmuş geometrik desenlerden meydana gelir. Bu geometrik panellerin aralarında 5 adet baba taşı yer almaktadır. Nehrin izlenmesine olanak veren bu alan ayrıca kitabe köşkünün de net olarak görülmesini sağlar. Köprü günümüze sağlam bir durumda ulaşabilmiştir. Yaya ve araç trafiğine açık durumda bulunmakta ve günümüzde kullanılmaktadır.

\section{DEĞERLENDİRME VE SONUÇ}

Yapılan araştırmada incelenen örneklerin gerek bölgesel gerek dönemsel ortak noktalarının bulunması nedeniyle benzer özelliklere sahip oldukları görülür. Ana malzeme olarak taş kullanımı bu duruma örnek olarak verilebilir. Konu edilen köprülerin inşalarında farklı bir malzeme kullanımına rastlanmaz. Taşın kullanım şekli köprülerin görünüm ve özelliklerinde farklılıklara neden olabilir. Muradiye mahallesinde yer alan Taş Köprü dışında kalan örneklerin taşı genellikle düzgün kesme olarak kullanıldıkları görülür. Bu durum aynı temel malzemenin farklı kullanım şekillerinin yarattığı farkı ortaya koymaktadır.

İncelenen köprülerin tamamı aynı suyolu üzerinde yer almaz. Saraçhane, II. Beyazıd ve Fatih Köprüleri Tunca nehri üzerinde yer almalarıyla ortak bir noktaya sahiptirler. Uzunköprü Ergene nehri üzerinde yer alırken Muradiye taş köprü ise günümüzde herhangi bir suyolu üzerinde bulunmamaktadır. Bu örnek dışındaki bütün köprülerde sel yaran ve tahliye gözü kullanımına rastlanir.

Edirne'deki köprülerin inşa edilmesinde bulundukları su yatağının yıl içerisindeki genişlemesinin yapım aşamasında dikkate alındığı Uzunköprü örneğinde olduğu gibi karşımıza çıkar. Yağışlarla genişleyip derinleşen su yatakları çok gözlü köprülerde suyun aktığı göz sayısının yıl içerisinde değişmesine neden olabilmektedir. Yağışların normal seyrettiği zamanlarda Uzunköprü'de 2, II. Beyazıd Köprüsü'nde 3-4, Saraçhane Köprüsü'nde 5-6, Fatih Köprüsünde 3 gözden su akışı olduğu gözlemlenir.

Muradiye 'de yer alan taş köprü ise herhangi bir suyolu üzerinde yer almayışılla aynı yüzyıla tarihlenen bu köprülerden ayrılır. Kimi durumlarda ise sel söz konusu olduğunda köprülerin gözlerinin tümüyle dolmasına hatta tamamen suya gömülmesine rastlanır. Bu durumun önüne geçilebilmesi için su yatakları genişletilme çalışmaları yapılmakta ve köprülerin zarar görmesi engellenmeye çalışılmaktadır.

Ele alınan köprülerde süsleme özelliklerine bakıldığında süslemeye hiç yer vermeden sade bir biçimde ortaya konulan eserler olduğu gibi çeşitli bezemelere sahip eserlerinde bulunduğu görülür.

Muradiye Taş Köprü, II. Beyazıd Köprüsü ve Fatih Köprüsü'nde süslemesiz sade bir anlayış benimsenmişken Uzunköprü ve Saraçhane Köprüsü'nde süsleme ögelerine yer verilir. Süsleme unsuru taşıyan örneklerde geometrik, bitkisel ve hayvansal formda örnekler göze çarparken figürlü süslemeye rastlanmaz. Edirne' de farklı dönemlere tarihlenen bütün köprülerle birlikte ele alındığında 15. yüzyıl köprülerinde de genel olarak figürlü süslemeye hiçbir örnekte rastlanmaz. Ayrıca araştırma konusu olan köprülerde taş süsleme dişında herhangi bir süsleme çeşidine rastlanmamıştır.

İncelenen köprüler Muradiye Taş Köprü hariç günümüzde kullanılır ve işlevine uygun durumdadır. Sadece bu örnekte plansız yapılaşma sonucunda işlevini ve bulunduğu suyolunu kaybetme durumu söz konusudur. 
Yapılan araştırmada köprülerin yapım ya da onarım hakkında bilgi veren kitabelerin bulunmasının kesin bir şart olmadığı sonucu çıkarılabilir. Köprülerde kimi zaman hiçbir kitabe yer almazken kimi zaman ise kitabeler farklı alanlara aktarılmış, inşa kitabesinin yerini onarım kitabesi almışken karşımıza çıkabilirler. Fatih, II. Beyazıd ve Muradiye köprülerinde kitabe bulunmaz. Saraçhane köprüsünde kitabe köşkü üzerinde yer alırken Uzunköprü örneğinde köprü çıkışında yer alan bir çeşme üzerine nakledilmiştir.

Edirne köprüleri bulundukları ortak coğrafya nedeniyle malzeme yönünden hemen her yüzyılda benzerlik gösterseler de yapım nedeni, işlevi, bulunduğu konum gibi nedenlerde boyut olarak oldukça farklı ölçütlere sahip olabilirler. Fatih Köprüsü sadece 3 göze sahipken Uzunköprü'nün 174 göze sahip olması bu farklılığa örnek olarak gösterilebilir. Aynı zamanda yaptıran kişinin istekleri ve zevkleri doğrultusunda farklı mimari ögeler, özellikler, farklı süsleme tarzlarıyla karşımıza çıkabilirler. Çalışmada incelenen 15. yüzyıl köprüleri içinde bu durum geçerli olmaktadır. Bu nedenle de yapı grubu olarak bir bütün halinde fakat taşıdıkları kendine has özellikleri bakımından tek tek incelendiklerinde, ait oldukları döneme dair en net bilgileri ortaya koymaktadırlar.

\section{KAYNAKÇA}

Aslanpa, O. (2005). Osmanlı Devri Mimarisi. İstanbul: İnkilap Yayınevi.

Çulpan, C. (1975). Türk Taş Köprüleri (Ortaçağdan Osmanlı Devri Sonuna Kadar). Ankara: Türk Tarih Kurumu Yayınları

Çulpan, C. (1968). Köprülerde Tarih Köşkleri. Journal of Art History, (2), 24-35. Retrieved from https://dergipark.org.tr/tr/pub/iusty/issue/34471/381793

Edirne Taşınmaz Kültür Varlıkları Envanteri Cilt I - II. (2013). Edirne: Edirne Valiliği Yayınları.

Edirne Belediyesi İmar ve Şehircilik Müdürlüğü Vaziyet Planı 2019

Fatih Köprüsü Röleve Raporu.

İlter, İ. (1965). Gazimihal ve Yıldırım Köprüleri. Sayı: 180. s.16-19.

Oral, O. (1972) Edirne Türk Tarih Vesikalarından Kitabeler. İstanbul: Yenilik Basımevi

Pekin, F. ve Yılmaz H. F. (2008). Türkiye'nin Kültür Mirası 100 Köprüu. İstanbul: NTV Yayınları

Sözen, M. ve Tanyeli, U. (2003) Sanat Kavram ve Terimleri Sözlüğü. İstanbul: Remzi Kitabevi

Tuğlacı, P. (1985). Osmanlı Şehirleri. İstanbul: Milliyet Yayınları.

Tunç, G. (1978). Taş Köprülerimiz. Ankara: Karayolları Matbaası. 